\title{
N-Monoacylation of Sulfonimidamides
}

\section{Yantao Chen*}

AstraZeneca Innovative Medicines Cardiovascular and Metabolic Diseases, 43183 Mölndal, Sweden yantao.chen@astrazeneca.com<smiles>O=C([P])Cl</smiles><smiles>c1ccnnc1</smiles>

1:1 premixed in $\mathrm{MeCN}$

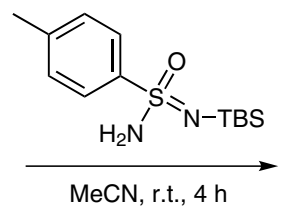

$\mathrm{MeCN}$, r.t., $4 \mathrm{~h}$

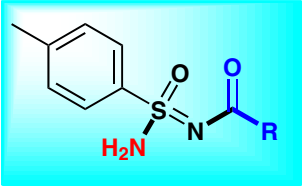

17 examples up to $96 \%$ yield $1: 1$ stoichiometry $\mathrm{NH}_{2}$ can be functionalized
Received: 02.11.2015

Accepted after revision: 07.01.2016

Published online: 26.01 .2016

DOI: 10.1055/s-0035-1561339; Art ID: ss-2015-t0639-op

Abstract $\mathrm{N}$-Monoacylated sulfonimidamides, the aza analogue of $\mathrm{N}$ acylsulfonamides which are a common motif in drug discovery, were exclusively synthesized by using a 1:1-premixed mixture of an acyl chloride and pyridazine as the acylating agent, while diacylation exclusively occurred when $N$-ethyl- $N$ '-(3-dimethylaminopropyl)carbodiimide (EDC) was used as the coupling agent. The monoacylation is fast, easy to operate, and applicable to both aromatic and aliphatic acyl chlorides to give the corresponding products in moderate or high overall yields. A two-step $N, N^{\prime}$-diacylated product exemplifies that the sulfonimidamide moiety provides one more handle than its sulfonamide isostere. This stepwise functionalization approach can be used to fine-tune the desired properties of compounds in medicinal chemistry.

Key words $N$-monoacylation, $N, N^{\prime}$-diacylation, sulfonimidamides, sulfonamides, pyridazine, lead optimization
The $\mathrm{N}$-acylsulfonamide moiety is a common motif incorporated in several recent developmental drugs such as AZD1283, a potent antagonist of the $\mathrm{P}_{2} \mathrm{Y}_{12}$ receptor, ${ }^{1}$ Simeprevir, a macrocyclic drug for the treatment and cure of hepatitis $\mathrm{C}$ virus, ${ }^{2}$ Repertaxin, a function blocker of the CXCR2 receptor, ${ }^{3}$ and Selexipag, a member of a novel class of prostacyclin receptor agonists ${ }^{4}$ (Figure 1 ).

Sulfonimidamides as the isosteric replacements for sulfonamides have received less attention from the scientific community than sulfonamides. From a synthetic chemistry perspective, acylsulfonimidamides have been used as a nitrene resource for the synthesis of sulfimides, sulfoximines, and aziridines. ${ }^{5}$ Recently, sulfonimidamides have been proposed as bioisosteres of sulfonamides and carboxylic acids in medicinal chemistry. ${ }^{6,7}$ In particular, the sulfonimidamide moiety provides one more handle (on the imidic ni-<smiles>CCOC(=O)c1cc(C#N)c(N2CCC(C(=O)NS(=O)(=O)C3(C)CC4CCCC3C4)(C(F)(F)F)CC2)nc1C</smiles>

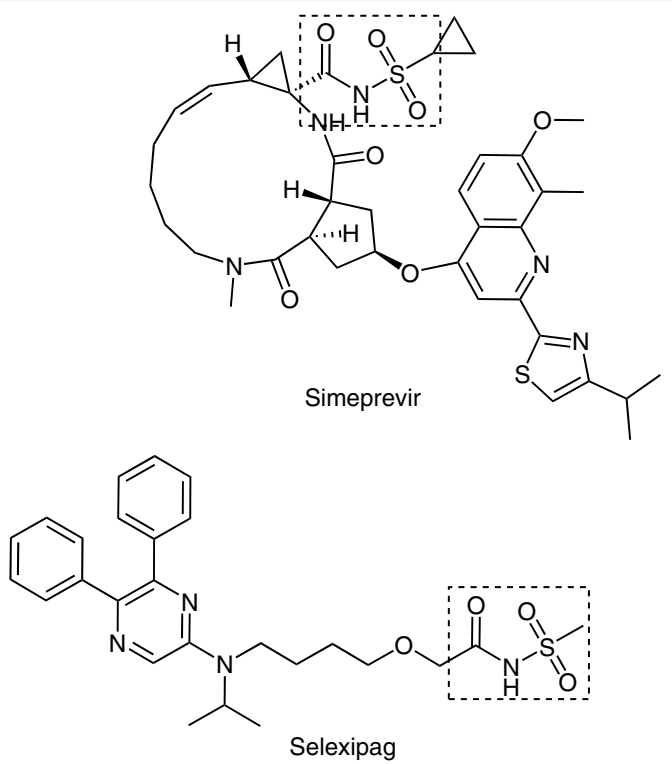<smiles>C=C(C(=O)NS(=O)(=O)C1CC2CCCCC21)c1ccc(CC(C)C)cc1</smiles>

Repertaxin

Figure $1 \mathrm{~N}$-Acylsulfonamides in biologically active compounds 
trogen atom) than its sulfonamide isostere; both the amidic and the imidic nitrogen atoms can be functionalized with the same or different functional groups (Figure 2). A stepby-step functionalization of both nitrogen atoms can potentially be applied in medicinal chemistry.

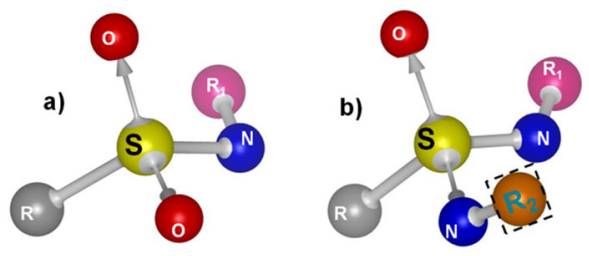

Figure 2 The sulfonamide moiety (a) and its isostere (b), sulfonimidamide, in which a new synthetic handle $\left(R^{2}\right)$ is introduced

The main synthetic contributions in the area of acylsulfonimidamides date back to the 1960s when Levchenko and Berzina developed preparative routes through the interaction of sulfonimidoyl chlorides with amines, ${ }^{8}$ routes which are still used to date. Recently, Pemberton ${ }^{7}$ and Bolm ${ }^{9,10}$ and their co-workers have employed acyl groups as protecting groups in sulfonimidamide chemistry. Acylsulfonimidamides as final products were first synthesized through the $\mathrm{N}$-functionalization of sulfonimidamides by Arvidsson and co-workers via Pd-catalyzed carbonylation of Boc-protected primary sulfonimidamides with aryl halides using a twochamber system. ${ }^{11}$ To date, there is no general method for the preparation of $\mathrm{N}$-monoacylated sulfonimidamides by a direct acylation of primary sulfonimidamides.

Due to the feasibility of TBS-protection/deprotection chemistry, the sulfonimidamide compound $\mathbf{1}$, which was prepared using a one-pot procedure starting from easily available 4-tolylsulfonamide, ${ }^{12}$ was initially employed in this work (Scheme 1). We kept the TBS group in the starting material to avoid $N, N^{\prime}$-diacylation during the reaction course. Meanwhile, we also expected that TBS deprotection could occur in situ under the reaction conditions. Thus, four products may be formed when mixing $\mathbf{1}$ with acylating agents: 2, a byproduct through TBS cleavage from the starting material; 3, the expected product; 4 , the unwanted $N, N$ '-diacylated byproduct; and 5, the TBS-protected product. It is noteworthy that synthesis of the enantiopure $S$ form of $\mathbf{3}$ was reported by Bolm and co-workers via a straightforward approach: 1) formation and epimerization of the menthyl ester of 4-toluenesulfinic acid sodium salt, 2 ) chiral ester to amide transformation, 3) protection of the chiral sulfonamide, 4) oxidative chlorination using tert-butyl hypochlorite, and 5) subsequent amination of the chiral sulfonimidoyl chloride. ${ }^{9}$ In this work, having $\mathbf{1}$ at hand, we aimed for its direct $N$-monoacylation with various acylating agents, which were prepared in situ from carboxylic acids or carbonyl chlorides.

As we have previously reported, ${ }^{12}$ treating 1 under acidic conditions leads to the formation of $\mathbf{2}$, the TBS-deprotected product. The diacylated compound $\mathbf{4}$ is also undesired, but is always formed when common amide coupling agents, such as 1-ethyl-3-(3-dimethylaminopropyl)carbodiimide (EDC), are employed. We looked for an ideal condition which not only provides high conversion of 1 into 3 exclusively, but also suppresses the formation of $\mathbf{4}$. We report here the test results of $N$-monoacylation via nucleophilic substitution of $\mathbf{1}$ with various acylating agents at a $0.05-$ mmol scale using acetonitrile as the solvent, and finally the synthesis of $17 \mathrm{~N}$-monoacylated sulfonimidamides, scaled up to $1.0 \mathrm{mmol}$, in moderate to excellent overall yields under mild conditions.

According to the hypothesis by Malacria and co-workers, the sulfonimidoylamide tautomer of $\mathbf{3}$ is assumed to undergo the tautomerization equilibrium as shown in Scheme 1 to give 3, the more stable isomer. ${ }^{5}$ Most recently, Arvidsson and co-workers have applied initial density functional theory calculations on a similar tautomeric equilibrium, and have claimed that the tautomeric form in which the $\mathrm{S}=\mathrm{N}$ bond is conjugated to the carbonyl group, i.e. $\mathbf{3}$, should be more stable than its sulfonimidoylamide tautom-

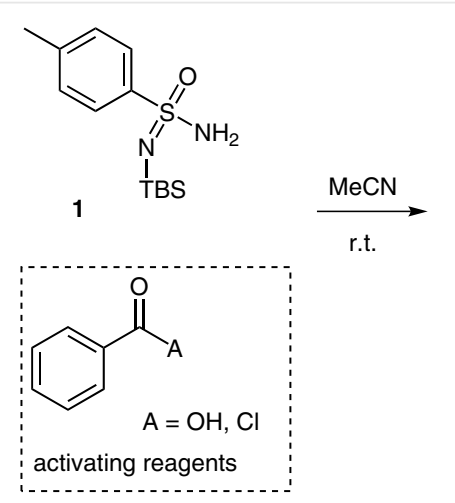

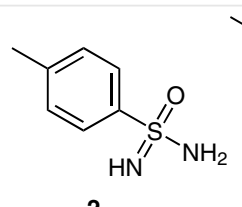

2<smiles>Cc1ccc(S(=O)(=NC(=O)c2ccccc2)NC(=O)c2ccccc2)cc1</smiles>

4<smiles>Cc1ccc(S(=N)(=O)N=C(N)c2ccccc2)cc1</smiles>

sulfonimidoylamide tautomer<smiles>Cc1ccc(S(=O)(=NC(=O)c2ccccc2)N[AsH3])cc1</smiles>

5

Scheme 1 Test reactions towards the synthesis of $\mathrm{N}$-acylsulfonimidamides 3 
er. ${ }^{13}$ The structures of other monoacylated products in this paper are drawn in a similar way as $\mathbf{3}$, by analogy.

Initially, the direct condensation of benzoic acid with $\mathbf{1}$ in the presence of EDC and DMAP, common coupling conditions for the synthesis of $\mathrm{N}$-acylsulfonamides, was conducted for the synthesis of 3 . The area percentage of each LCMS peak is reported without adjustment. According to the LCMS results, the polarity is in the order $\mathbf{2}>\mathbf{3}>\mathbf{4}>\mathbf{5}>\mathbf{1}$ (Table 1).

Table 1 Synthesis of 3 from Benzoic Acid Using EDC as Coupling Agent

\begin{tabular}{lcccc}
\hline Entry $^{\mathrm{a}}$ & $\mathbf{1}(\boldsymbol{\mu \mathrm { mol } )}$ & DMAP $(\boldsymbol{\mu m o l})$ & Time $(\mathrm{h})$ & $\mathbf{2 / 3 / 4 / 5 / 1}(\%)^{\mathrm{b}}$ \\
\hline 1 & 50 & 25 & 4 & $3: 0: 22: 0: 26$ \\
2 & 50 & 25 & 20 & $0: 0: 33: 0: 22$ \\
3 & 50 & 50 & 4 & $2: 0: 20: 0: 20$ \\
4 & 50 & 50 & 20 & $0: 0: 27: 0: 18$ \\
5 & 50 & 100 & 4 & $0: 0: 16: 0: 15$ \\
6 & 50 & 100 & 20 & $0: 0: 23: 0: 14$ \\
7 & 100 & 100 & 20 & $0: 0: 24: 0: 19$ \\
8 & 200 & 100 & 20 & $0: 0: 23: 0: 24$
\end{tabular}

${ }^{a}$ Reaction conditions: benzoic acid $(50 \mu \mathrm{mol})$, EDC $(50 \mu \mathrm{mol}), \mathrm{MeCN}$

(1 mL), r.t.

${ }^{b}$ Conversion of each peak by LCMS, performed under basic column conditions ( $\mathrm{pH} \mathrm{10)}$ using a total ion current (TIC) detector.

Under these coupling conditions, none of the test reactions (Table 1 ) gave the monoacylated product 3 , regardless of the reaction time or the amount of base (DMAP) used. Surprisingly, acylation under habitual conditions, such as using an excess of $\mathbf{1}$, did not give the monoacylated product 3 at all (Table 1, entries 7 and 8). Instead, the unexpected $N, N^{\prime}$-diacylated byproduct 4 was formed exclusively, besides 1 and 2. Similar to 3, the diacylated compound $\mathbf{4}$ has two tautomeric forms, $\mathbf{4 A}$ and $\mathbf{4 B}$, which are actually identical (Figure 3).

In order to obtain the $N, N^{\prime}$-diacylated byproduct $\mathbf{4}$ for structural analysis purposes, a $0.5-\mathrm{mmol}$ scale reaction was performed using 2 equivalents of benzoic acid and of EDC. Interestingly, $\mathrm{NMR}\left(\mathrm{CDCl}_{3}\right.$ as solvent) analysis revealed that the $\mathrm{NH}$ proton in $\mathbf{4}$ was not visible in the ${ }^{1} \mathrm{H}$ NMR spectrum, and no carbonyl peak was visible in the ${ }^{13} \mathrm{C}$ NMR spectrum either (Figure 4). We think that, due to fast proton exchange, the acidic proton moves between $\mathrm{O}$ and $\mathrm{N}$. This tautomerization makes the acidic proton invisible in the ${ }^{1} \mathrm{H}$ NMR spectrum. Due to the symmetry of the two acyl groups, the tautomerization also makes the carbonyl peak invisible in the ${ }^{13} \mathrm{C}$ NMR spectrum. According to the calculations of Arvidsson and co-workers, ${ }^{13}$ the lowest energy tautomer adopts a conjugated conformation. Taken all together, we assume that the tautomer $\mathbf{4 A}$ (or $\mathbf{4 B}$, as they are identical), is the most stable isomer. In order to see the carbonyl carbon peak, a trace amount of TFA $(2 \mu \mathrm{L})$ was added to the NMR sample, which resulted in the carbonyl peak being visible at $169.8 \mathrm{ppm}$ as a singlet. It is believed that protonated $\mathbf{4 A} / \mathbf{4 B}$ is the stable resonance hybrid when the sample is treated with TFA, which makes the carbonyl peak visible. In this paper, we will continue to depict $\mathbf{4}$ as the diacylated structure, although $\mathbf{4 A}$ is assumed to be the real structure.

It is well known that the formation of diacylated byproducts is the most important restriction when a base such as pyridine or DMAP is employed in the synthesis of acylsulfonamides. To avoid the formation of $\mathrm{N}, \mathrm{N}$-diacylated sulfonamide byproducts, an acid-catalyzed reaction of carboxylic acid anhydrides or esters with amines is often applied. ${ }^{14-17}$ As noted, we thought that the TBS-deprotected compound 2 could be diacylated to afford the undesired compound 4; therefore, the TBS-protected compound 1 was used in this work. Considering the undesired lability of $\mathbf{1}$ under acidic conditions, we focused on finding other acylating systems, using either benzoic acid or benzoyl chloride under basic conditions (Scheme 2).

When benzoic acid was used, one equivalent of triethylamine was added before the addition of different activating agents to prepare the relevant acylating agents ${ }^{18-21}$ (Table 2, entries 1, 3-5); when benzoyl chloride was used, the acylating agent was prepared by simply mixing the acyl chloride and one equivalent of pyridine 22 (Table 2 , entry 2 ). The acylation reactions were examined by LCMS after different reaction times, and the area percentage of each peak $(\mathbf{2}, \mathbf{3}, \mathbf{4}$, $\mathbf{5 , 1}$ ) determined. The results are summarized in Table 2.

Carbonyldiimidazole was used as the activating agent for Table 2, entry 1; for entry 2, a mixture of benzoyl chloride and pyridine was prepared before the addition of $\mathbf{1}$; for entries 3-5, dichlorotriphenylphosphorane, dimethylchlo-

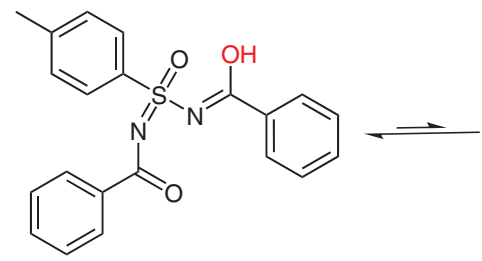

4A

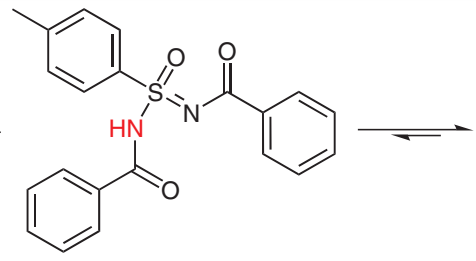

4

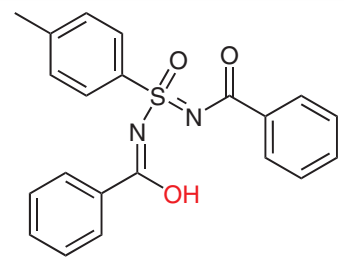

$4 B$

Figure 3 Possible tautomers of 4 


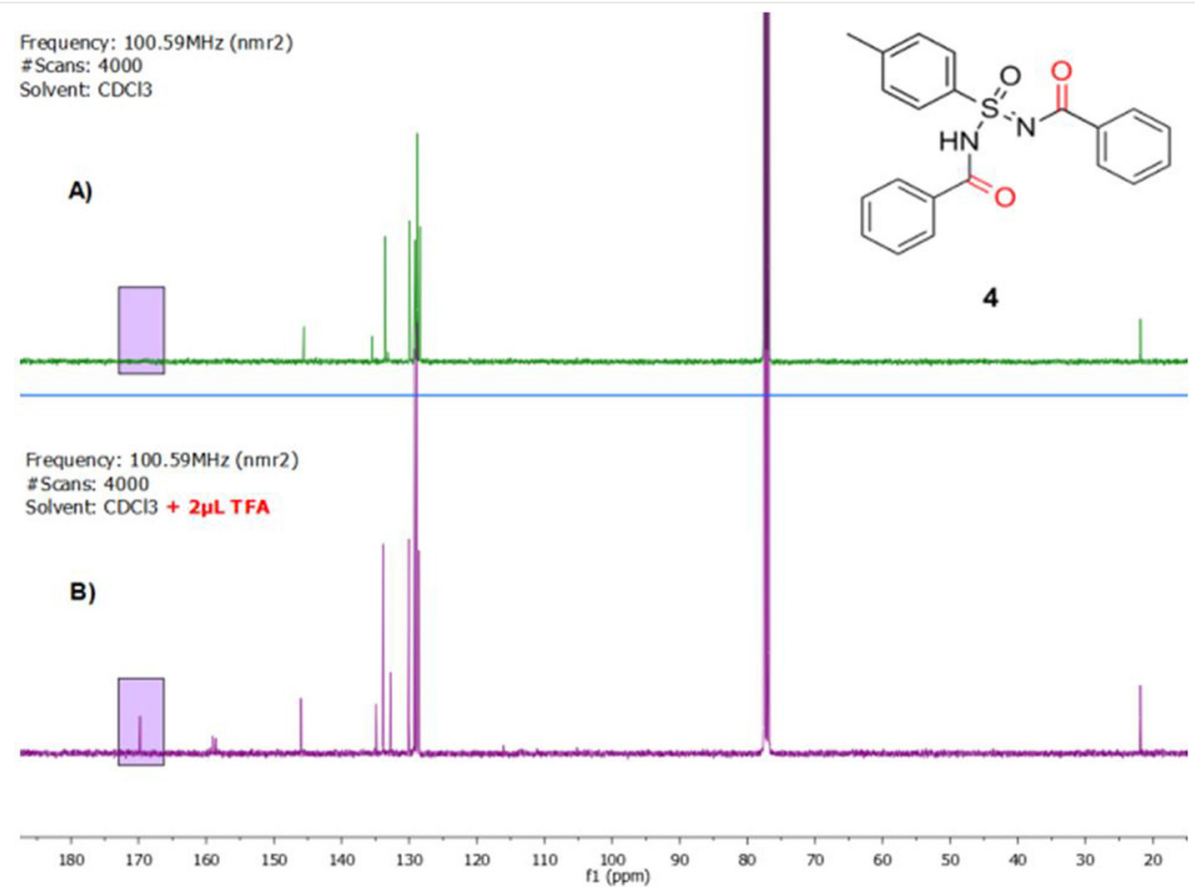

Figure $4{ }^{13} \mathrm{C}$ NMR spectra of 4: A) carbonyl peak not visible $\left(\mathrm{CDCl}_{3}\right)$; B) carbonyl peak visible after addition of TFA

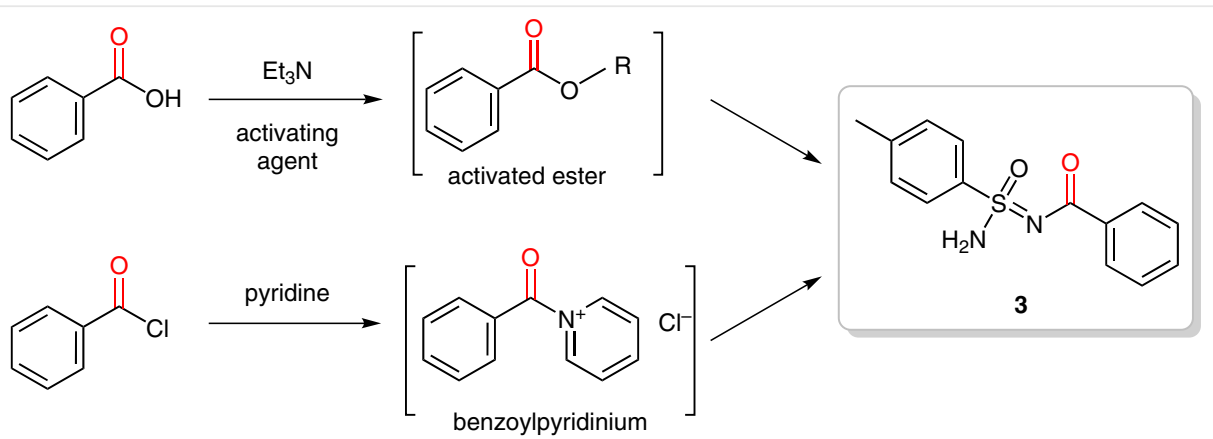

Scheme 2 Two possible acylation approaches

roformiminium chloride (Vilsmeier reagent), and TBTU, respectively, were utilized as activating agents. Because our aim was to find an easy-to-make and efficient acylating agent, all acylating agents in Table 2 were prepared in situ and directly used for acylation chemistry without isolation. We were delighted to observe that 1-benzoylpyridin-1-ium chloride (Table 2, entry 2) showed the best conversion of $\mathbf{1}$ into 3, with a long reaction time ( $24 \mathrm{~h}$ ) only showing a slightly better conversion (63\%). Additionally, compared with all other acylating reagents, this reagent can be easily prepared by just mixing benzoyl chloride with pyridine, and a stock solution of the mixture in acetonitrile is stable for at least 40 days with storage at room temperature.
However, while good conversion was observed when pyridine was used, the undesired $N, N^{\prime}$-diacylated byproduct 4 was also formed (Table 2, entry 2). In 2002, Osajda and Mlochowski studied the reaction of benzoyl chloride with pyrazine or pyridazine, a pyridine-like heterocyclic base. ${ }^{23}$ We were curious to see if other pyridine-like replacements could improve our conversion, and ideally suppress the formation of the $N, N^{\prime}$-diacylated byproduct 4 . Therefore, acylating agents were prepared by mixing benzoyl chloride with 1 equivalent of different bases in acetonitrile. Pyrazine and pyridazine, which were used by Osajda and Mlochowski, ${ }^{23}$ together with other aliphatic tertiary amines, were used with benzoyl chloride to form quaternary ammonium salts (Table 3 ). The other conditions, such as concentration and 
Table 2 Acylating Agent Screening towards the Synthesis of 3

\begin{tabular}{|c|c|c|c|}
\hline Entry ${ }^{a}$ & Acylating agent & $\begin{array}{l}2 / 3 / 4 / 5 / 1(\%)^{b} \\
(6 \mathrm{~h})\end{array}$ & $\begin{array}{l}2 / 3 / 4 / 5 / 1(\%)^{b} \\
(24 \mathrm{~h})\end{array}$ \\
\hline
\end{tabular}

1<smiles>O=C(c1ccccc1)n1ccnc1</smiles>

10:0:0:17:36 9:0:0:18:58<smiles>O=C(c1ccccc1)[n+]1ccccc1</smiles>

12:58:12:11:0

10:63:14:6:0

3<smiles>O=C(O[P+]([O-])(c1ccccc1)c1ccccc1)c1ccccc1</smiles>

11:45:0:0:0<smiles>C[N+](C)=COC(=O)c1ccccc1</smiles>

18:16:0:0:0

17:16:0:0:0

4 $\mathrm{Cl}^{-}$

5

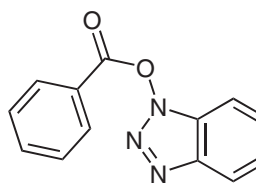

$68: 3: 0: 2: 27$

39:22:0:0:27

aeaction conditions: 1 (0.05 mmol), acylating agent $(0.05 \mathrm{mmol}), \mathrm{MeCN}$ $(1 \mathrm{~mL})$, r.t.

${ }^{b}$ LCMS was run under basic column conditions ( $\left.\mathrm{pH} 10\right)$, and the area percentage was determined using a TIC detector.

temperature, are identical to those used for Table 2, entry 2. The area percentage of each LCMS product/byproduct peak is shown in Table 3 at different reaction times; pyridine was used as a reference in this screening (entry 1 ).

Gratifyingly, the LCMS spectrum of entry 3 (Table 3 ) showed that 3 was formed exclusively in 4 hours with 100\% conversion. The TBS group in $\mathbf{1}$ is readily deprotected during the reaction course, presumably due to the acidity of the pyridazine hydrochloride salt, which is formed from the acylation chemistry. The acylating agent used for Table 3 , entry 2 was also better than that used for entry 1 , but the reaction was slower; in general, $\mathbf{3}$ was the predominant product and byproduct 5 was negligible for entries $1-3$. For entries 4 and 5 (Table 3 ) the complex did not form the expected product 3 , but mainly the TBS-deprotected byproduct 2 and the diacylated 4 . Ultimately, we replaced pyridine by pyridazine as the base to form different acylating agents with different acyl chlorides. It is noteworthy that when this replacement was made, the acylating mixture (Table 3, entry 3) turned a brown color after $10 \mathrm{~h}$. Practically, on a large scale ( $1 \mathrm{mmol})$, a mixture of the fresh acylating agent was prepared by mixing acyl chloride and pyridazine in a 1:1 ratio in acetonitrile, then stirred for 1 minute before a
Table 3 Acylating Agent Screening towards the Synthesis of 3

\begin{tabular}{lll}
\hline Entry $^{\mathrm{a}} \quad$ Acylating agent & $\begin{array}{l}\mathbf{2 / 3 / 4 / 5 / 1}(\%)^{\mathrm{b}} \\
(4 \mathrm{~h})\end{array}$ & $\begin{array}{l}\mathbf{2 / 3 / 4 / 5 / 1}(\%)^{\mathrm{b}} \\
(24 \mathrm{~h})\end{array}$ \\
\hline
\end{tabular}

1<smiles>O=C(c1ccccc1)[n+]1ccccc1</smiles>

$16: 50: 11: 19: 4$

10:67:11:9:4

2<smiles>O=C(c1ccccc1)[n+]1ccncc1</smiles>

19:64:3:0:0

9:82:0:0:0

3<smiles>O=C(c1ccccc1)[n+]1ccccn1</smiles>

0:100:0:0:0

$0: 100: 0: 0: 0$

4<smiles>CC[N+](CC)(CC)C(=O)c1ccccc1</smiles>

23:0:20:0:40

20:0:22:0:45

5<smiles>C[N+]1(C(=O)c2ccccc2)CCOCC1</smiles>

22:0:0:0:49

$18: 0: 5: 0: 44$ a Reaction conditions: 1 ( $0.05 \mathrm{mmol})$, acylating agent $(0.05 \mathrm{mmol}), \mathrm{MeCN}$
$(1 \mathrm{~mL})$, r.t.
b LCMS was run under basic column conditions ( $\mathrm{pH} 10)$, and the area per-
centage was determined using a TIC detector.

stock solution of $\mathbf{1}$ in acetonitrile was added; then, the reaction mixture was stirred at room temperature for 4 hours until LCMS indicated full conversion (Scheme 3).

In most cases, the synthetic protocol worked well for both aromatic and aliphatic acyl chlorides. It also tolerated heteroaromatic acyl chlorides. Functional groups such as esters are also compatible with the reaction conditions. When 4-(dimethylamino)benzoyl chloride was used, both 9 and the diacylated byproduct $\mathbf{1 0}$ were isolated, although the latter was in a notably low yield. When pyridinoyl chloride hydrochlorides were used, 2 equivalents of pyridazine were used. The meta- and para-pyridyl products $\mathbf{1 3}$ and $\mathbf{1 5}$ were isolated in moderate yields; however, the synthesis of the ortho analogue 14 using this protocol was not successful. The isolated yield of $\mathbf{1 4}$ was remarkably low (10\%); LCMS analysis of the reaction mixture showed many unknown impurities and $46 \%$ unreacted starting material. In other cases, monoacylated products were isolated in moderate or high overall yields.

Acylsulfonimidamides such as $\mathbf{3}$ can be further modified (see Figure 2, b). For example, Malacria and co-workers have reported the synthesis of $N$-acyl- $N^{\prime}$-arylsulfonimidamides, via the copper-catalyzed $\mathrm{N}$-arylation of primary sulfonimidamide $\mathbf{3}$, in which both $\mathrm{N}$ atoms in the sulfonim- 
idamide structure were functionalized. ${ }^{24}$ Besides arylation, the structural features of $\mathbf{3}$ allow other $\mathrm{N}$-functionalization such as alkylation and acylation. As previously mentioned, when benzoic acid was used as the acylating source, and EDC as the coupling agent, $N, N^{\prime}$-diacylation was exclusively achieved (through $N$-acylation $+N^{\prime}$-acylation). Having 3 at hand, we used butanoyl chloride as the second acylating source and triethylamine as the base. The reaction, which was monitored by LCMS, went to completeness in 40 minutes in high isolated yield (Scheme 4). We believe that this step-by-step functionalization is more useful as it can introduce different variations on the two nitrogens, which can potentially be applied in medicinal chemistry.
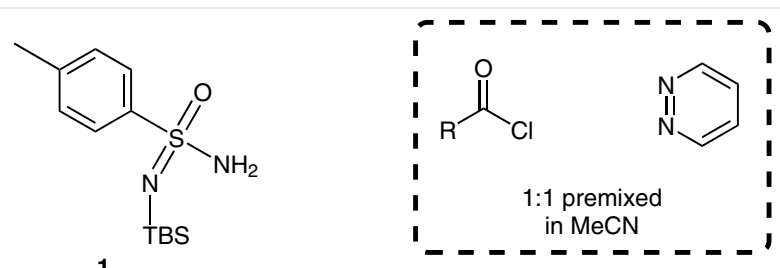

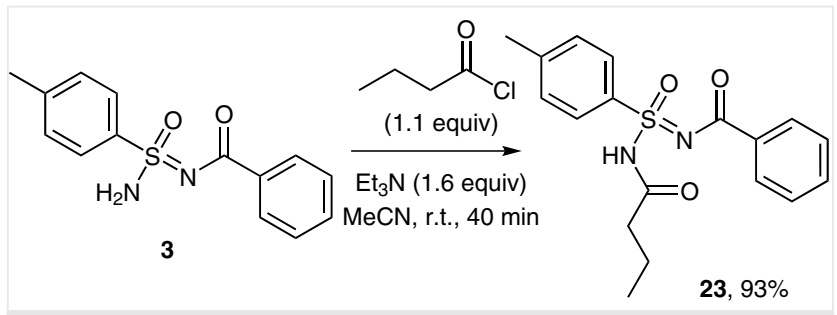

Scheme 4 An example of further $N$-functionalization of 3

In summary, an unprecedented method for the $\mathrm{N}$ monoacylation of primary sulfonimidamides has been developed using a 1:1 premixed mixture of an acyl chloride

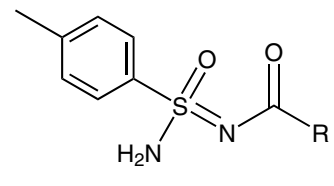

17 examples<smiles>COC(=O)c1ccc(C(=O)N=S(N)(=O)c2ccc(C)cc2)cc1</smiles>
3, $96 \%^{\mathrm{a}}$

6, $37 \%$

$7,52 \%$

8, $94 \%$

9, 33\%<smiles>CNc1ccc(C(=O)N=S(=O)(NC(=O)c2ccc(N(C)C)cc2)c2ccc(C)cc2)cc1</smiles>

$15,56 \%{ }^{\mathrm{c}}$<smiles>COc1ccc(C(=O)N=S(N)(=O)c2ccc(C)cc2)cc1</smiles>

$11,35 \%$<smiles>Cc1ccc(S(N)(=O)=NC(=O)c2cc(C)on2)cc1</smiles>

$16,75 \%$

$12,36 \%$<smiles>CCOC(=O)CC(=O)N=S(N)(=O)c1ccc(C)cc1</smiles>

$17,35 \%$<smiles>Cc1ccc(S(N)(=O)=NC(=O)c2cccnc2)cc1</smiles>

$13,45 \%^{\mathrm{c}}$

$14,10 \%^{\mathrm{c}}$<smiles>CCOC(=O)CCC(=O)N=S(N)(=O)c1ccc(C)cc1</smiles>

$18,71 \%$<smiles>CCCC(=O)N=S(N)(=O)c1ccc(C)cc1</smiles>

19, $79 \%$<smiles>Cc1ccc(S(N)(=O)=NC(=O)C(C)(C)C)cc1</smiles>

20, $92 \%$<smiles>Cc1ccc(S(N)(=O)=NC(=O)COCc2ccccc2)cc1</smiles>

$21,78 \%$<smiles>CCOC(=O)N=S(N)(=O)c1ccc(C)cc1</smiles>

22, $93 \%$

Scheme 3 Monoacylation of $\mathbf{1}$ with acylating agents. ${ }^{a}$ Isolated yield in all cases. ${ }^{\mathrm{b}}$ Byproduct $\mathbf{1 0}$ isolated along with $\mathbf{9}$. c Pyridazine (2 mmol) was used because the acyl chlorides were used as the $\mathrm{HCl}$ salts. 
and pyridazine as the acylating agent and one equivalent of sulfonimidamide; the reaction proceeds under mild conditions in moderate to excellent yields. In contrast, the $N, N^{\prime}-$ diacylated byproduct 4 is exclusively formed when EDC is used as the coupling agent. A step-by-step acylation with two different acylating agents also illustrates this chemistry's potential by equipping an extra handle. Additionally, different substituents on the two nitrogen atoms creates chirality on the sulfur atom, which is also useful from a medicinal chemistry perspective. We consider that this direct monoacylation of sulfonimidamides will be valuable to provide further $N$-functionalized derivatives in medicinal chemistry or as ligands or auxiliaries in organometallic catalysis.

All reactions were carried out under an inert atmosphere with dried solvents under anhydrous conditions unless otherwise stated. Commercially available reagents including the Vilsmeier reagent were used without further purification. Melting points were measured on a Büchi 510 apparatus, without correction. ${ }^{1} \mathrm{H}$ and ${ }^{13} \mathrm{C}$ NMR spectra were recorded on a Bruker Avance II spectrometer at $25{ }^{\circ} \mathrm{C}$, using $\mathrm{CDCl}_{3}, \mathrm{CD}_{3} \mathrm{OD}$, or DMSO- $d_{6}$ as the solvent. Data for ${ }^{1} \mathrm{H}$ NMR spectra are reported as follows: chemical shift $(\delta, \mathrm{ppm})$, multiplicity, coupling constants $(\mathrm{Hz})$, integration. Chemical shifts are reported relative to the residual undeuterated solvent signals. High-resolution mass spectrometry was performed by the Structure Analysis \& Separation Science Group, AstraZeneca R\&D Mölndal.

\section{(Z)-N-[N-Benzoyl-S-(4-methylphenyl)sulfonimidoyl]benzimidic Acid (4A)}

A mixture of benzoic acid stock solution in $\mathrm{MeCN}(0.28 \mathrm{M} ; 1.79 \mathrm{~mL}$, $0.5 \mathrm{mmol}), \mathrm{EDC} / \mathrm{DMAP}$ stock solution in MeCN [3.60 mL; EDC (0.5 $\mathrm{mmol})$, DMAP (0.25 mmol)], and DMAP stock solution in MeCN (2.7 $\mathrm{mL}, 0.75 \mathrm{mmol}$ ) was stirred at r.t. for $10 \mathrm{~min}$. To the mixture was added a stock solution of 1 in $\mathrm{MeCN}(5.97 \mathrm{~mL}, 0.5 \mathrm{mmol})$. The reaction mixture was stirred at r.t. for $18 \mathrm{~h}$. The LCMS peak area percentages of the diacylated product $\mathbf{4}$ and the starting material 1 were $25 \%$ and $12 \%$, respectively. To the mixture was then added a premixture of benzoic acid stock solution in $\mathrm{MeCN}(1.79 \mathrm{~mL}, 0.5 \mathrm{mmol})$ and EDC/DMAP stock solution [3.60 mL; EDC (0.5 mmol), DMAP $(0.25$ $\mathrm{mmol})$ ]. In total, $1(0.5 \mathrm{mmol})$, benzoic acid $(1.0 \mathrm{mmol})$, EDC (1.0 $\mathrm{mmol})$, and DMAP (1.25 mmol) were mixed in the reaction. After addition, the reaction was monitored by LCMS. The reaction mixture was stirred at r.t. for another $18 \mathrm{~h}$ until no more improvement (LCMS); however, there was still approx. $30 \%$ of unreacted starting material. The mixture was concentrated to dryness. The residue was purified by preparative HPLC on a Kromasil C8 column $(10 \mu \mathrm{m}, 250 \times$ $50 \mathrm{~mm}$ ID) using a gradient of $30-80 \% \mathrm{MeCN}$ in $\mathrm{H}_{2} \mathrm{O} / \mathrm{MeCN} /$ formic acid 95:5:0.2 buffer over $20 \mathrm{~min}$ with a flow rate of $100 \mathrm{~mL} / \mathrm{min}$ and $\mathrm{UV}$ detection at $240 \mathrm{~nm}$.

Yield: $64 \mathrm{mg}$ (34\%); off-white solid; $\mathrm{mp} 156-157^{\circ} \mathrm{C}$.

${ }^{1} \mathrm{H} \mathrm{NMR}\left(400 \mathrm{MHz}, \mathrm{CDCl}_{3}\right): \delta=8.08(\mathrm{~d}, J=7.4 \mathrm{~Hz}, 4 \mathrm{H}), 8.02(\mathrm{~d}, J=8.3$ $\mathrm{Hz}, 2 \mathrm{H}), 7.59(\mathrm{t}, J=7.4 \mathrm{~Hz}, 2 \mathrm{H}), 7.48(\mathrm{t}, J=7.7 \mathrm{~Hz}, 4 \mathrm{H}), 7.37(\mathrm{~d}, J=8.3$ $\mathrm{Hz}, 2 \mathrm{H}), 2.44(\mathrm{~s}, 3 \mathrm{H})$.

${ }^{1} \mathrm{H}$ NMR (400 MHz, $\left.\mathrm{CDCl}_{3}+2 \mu \mathrm{L} \mathrm{TFA}\right): \delta=8.06(\mathrm{dt}, J=1.7,8.7 \mathrm{~Hz}, 6 \mathrm{H}$ ), $7.60(\mathrm{t}, J=7.4 \mathrm{~Hz}, 2 \mathrm{H}), 7.48(\mathrm{t}, J=7.7 \mathrm{~Hz}, 4 \mathrm{H}), 7.39(\mathrm{~d}, J=8.3 \mathrm{~Hz}, 2 \mathrm{H})$, $2.46(\mathrm{~s}, 3 \mathrm{H})$.
${ }^{13} \mathrm{C}$ NMR $\left(101 \mathrm{MHz}, \mathrm{CDCl}_{3}\right): \delta=145.6,135.5,133.5,133.1,129.9$, 129.1, 128.8, 128.4, 21.9.

${ }^{13} \mathrm{C}$ NMR (101 MHz, $\mathrm{CDCl}_{3}+2 \mu \mathrm{L}$ TFA): $\delta=169.8,146.0,134.8,133.8$, $132.8,130.0,129.2,128.9,128.5,21.9$.

HRMS (ESI): $m / z$ [M $+\mathrm{H}]^{+}$calcd for $\mathrm{C}_{21} \mathrm{H}_{18} \mathrm{~N}_{2} \mathrm{O}_{3} \mathrm{~S}$ : 379.1116; found: 379.1113.

\section{Monoacylation; General Procedure}

To a solution of acyl chloride ( $1 \mathrm{mmol}$ ) in $\mathrm{MeCN}(4 \mathrm{~mL})$ was added 0.5 $\mathrm{M}$ pyridazine solution in $\mathrm{MeCN}(2 \mathrm{~mL})$. The mixture was stirred at r.t. for $1 \mathrm{~min}$. To the mixture was added a $0.25 \mathrm{M}$ stock solution of $\mathbf{1}$ in $\mathrm{MeCN}(4 \mathrm{~mL})$ in one portion. The resulting mixture was stirred at r.t. for $4 \mathrm{~h}$ until LCMS showed full conversion. After concentration, the product was purified either on a Biotage KP-Sil column (50 g) using a gradient of $10-80 \%$ EtOAc in heptane over 16 column volumes $(\mathrm{CV})$ as mobile phase, or by preparative HPLC on an XBridge C18 column (10 $\mu \mathrm{m}, 250 \times 50 \mathrm{~mm}$ ID) using a gradient of $0-50 \% \mathrm{MeCN}$ in $\mathrm{H}_{2} \mathrm{O} / \mathrm{MeCN} / \mathrm{NH}_{3}$ 95:5:0.2 buffer over 30 min with a flow rate of 100 $\mathrm{mL} / \mathrm{min}$. All products were collected using the wavelength $240 \mathrm{~nm}$.

\section{$\boldsymbol{N}$-[Amino(4-methylphenyl)oxido- $\boldsymbol{\lambda}^{\boldsymbol{6}}$-sulfanylidene]benzamide} $(3)^{9,24}$

Yield: $262 \mathrm{mg}$ (96\%); white solid; mp 137-139 ${ }^{\circ} \mathrm{C}$ (Lit. ${ }^{24} 143^{\circ} \mathrm{C}$ ).

${ }^{1} \mathrm{H}$ NMR (400 MHz, DMSO- $d_{6}$ ): $\delta=7.92-7.99(\mathrm{~m}, 2 \mathrm{H}), 7.82(\mathrm{~d}, J=8.3$ $\mathrm{Hz}, 2 \mathrm{H}), 7.76(\mathrm{~s}, 2 \mathrm{H}), 7.51(\mathrm{t}, J=7.3 \mathrm{~Hz}, 1 \mathrm{H}), 7.36-7.46$ (m, $4 \mathrm{H}), 2.38$ (s, $3 \mathrm{H})$.

${ }^{13} \mathrm{C}$ NMR $\left(101 \mathrm{MHz}\right.$, DMSO- $\left.d_{6}\right): \delta=171.2,142.7,139.6,136.2,131.7$, 129.3, 128.6, 128.0, 126.8, 21.0.

HRMS (ESI): $m / z[M+\mathrm{H}]^{+}$calcd for $\mathrm{C}_{14} \mathrm{H}_{14} \mathrm{~N}_{2} \mathrm{O}_{2} \mathrm{~S}: 275.0854$; found: 275.0860 .

Methyl 4-\{[Amino(4-methylphenyl)oxido- $\lambda^{6}$-sulfanylidene $]$ carbamoyl\}benzoate (6)

Yield: $122 \mathrm{mg}$ (37\%); yellow solid; $\mathrm{mp} 176-177^{\circ} \mathrm{C}$.

${ }^{1} \mathrm{H}$ NMR (400 MHz, DMSO- $d_{6}$ ): $\delta=7.97-8.10(\mathrm{~m}, 4 \mathrm{H}), 7.86(\mathrm{~s}, 2 \mathrm{H})$, $7.83(\mathrm{~d}, J=8.2 \mathrm{~Hz}, 2 \mathrm{H}), 7.40(\mathrm{~d}, J=8.2 \mathrm{~Hz}, 2 \mathrm{H}), 3.87(\mathrm{~s}, 3 \mathrm{H}), 2.38(\mathrm{~s}, 3$ $\mathrm{H})$.

${ }^{13} \mathrm{C}$ NMR $\left(101 \mathrm{MHz}\right.$, DMSO- $\left.d_{6}\right): \delta=170.2,165.8,142.9,140.2,139.2$, 132.1, 129.4, 129.1, 128.9, 126.9, 52.3, 20.96.

HRMS (ESI): $m / z[M+H]^{+}$calcd for $\mathrm{C}_{16} \mathrm{H}_{16} \mathrm{~N}_{2} \mathrm{O}_{4} \mathrm{~S}$ : 333.0909; found: 333.0910 .

Methyl 2-\{[Amino(4-methylphenyl)oxido- $\lambda^{6}$-sulfanylidene $]$ carbamoyl\}benzoate (7)

Yield: $173 \mathrm{mg}(52 \%)$; yellow oil.

${ }^{1} \mathrm{H} \mathrm{NMR}\left(400 \mathrm{MHz}, \mathrm{CDCl}_{3}\right): \delta=7.87-7.91(\mathrm{~m}, 2 \mathrm{H}), 7.79-7.84(\mathrm{~m}, 1 \mathrm{H})$, 7.54-7.58 (m, $1 \mathrm{H}), 7.41-7.47(\mathrm{~m}, 2 \mathrm{H}), 7.27(\mathrm{~d}, J=8.3 \mathrm{~Hz}, 2 \mathrm{H}), 6.35(\mathrm{~s}$, $2 \mathrm{H}), 3.76$ (s, $3 \mathrm{H}), 2.39$ (s, $3 \mathrm{H})$.

${ }^{13} \mathrm{C}$ NMR (101 MHz, $\left.\mathrm{CDCl}_{3}\right): \delta=174.3,171.3,169.6,144.6,137.9$, 137.0, 132.3, 130.7, 130.5, 129.8, 129.3, 129.2, 128.3, 126.9, 52.6, 21.7. HRMS (ESI): $m / z[M+H]^{+}$calcd for $\mathrm{C}_{16} \mathrm{H}_{16} \mathrm{~N}_{2} \mathrm{O}_{4} \mathrm{~S}$ : 333.0909; found: 333.0900 .

$N$-[Amino(4-methylphenyl)oxido- $\lambda^{6}$-sulfanylidene]-4-chlorobenzamide (8)

Yield: $289 \mathrm{mg}$ (94\%); white solid; $\mathrm{mp} 148-149^{\circ} \mathrm{C}$. 
${ }^{1} \mathrm{H}$ NMR (400 MHz, DMSO- $d_{6}$ ): $\delta=7.92-7.97(\mathrm{~m}, 2 \mathrm{H}), 7.81(\mathrm{~d}, J=8.1$ $\mathrm{Hz}, 4 \mathrm{H}), 7.46-7.52$ (m, $2 \mathrm{H}), 7.40$ (d, $J=8.1 \mathrm{~Hz}, 2 \mathrm{H}), 2.38(\mathrm{~s}, 3 \mathrm{H})$.

${ }^{13} \mathrm{C}$ NMR (101 MHz, DMSO- $\left.d_{6}\right): \delta=170.1,142.8,139.4,136.5,135.0$, $130.5,129.3,128.2,126.9,21.0$.

HRMS (ESI): $m / z[\mathrm{M}+\mathrm{H}]^{+}$calcd for $\mathrm{C}_{14} \mathrm{H}_{13} \mathrm{ClN}_{2} \mathrm{O}_{2} \mathrm{~S}$ : 309.0464; found: 309.0461 .

\section{$N$-[Amino(4-methylphenyl)oxido- $\lambda^{6}$-sulfanylidene]-4-(dimethyl- amino)benzamide (9)}

Yield: $106 \mathrm{mg}$ (33\%); off-white solid; $\mathrm{mp} 180-181^{\circ} \mathrm{C}$.

${ }^{1} \mathrm{H}$ NMR (400 MHz, DMSO- $d_{6}$ ): $\delta=7.78(\mathrm{~d}, J=8.6 \mathrm{~Hz}, 4 \mathrm{H}), 7.59(\mathrm{~s}, 2$ H), 7.37 (d, J = 8.2 Hz, $2 \mathrm{H}), 6.65$ (d, J = 9.0 Hz, $2 \mathrm{H}), 2.96$ (s, $6 \mathrm{H}), 2.37$ (s, $3 \mathrm{H})$.

${ }^{13} \mathrm{C}$ NMR $\left(101 \mathrm{MHz}\right.$, DMSO- $\left.d_{6}\right): \delta=171.4,152.5,142.3,140.4,130.3$, $129.2,126.7,123.2,110.4,20.9 ; \mathrm{N}\left(\mathrm{CH}_{3}\right)_{2}$ not visible here, but visible in the HSQC spectrum.

HRMS (ESI): $m / z[M+H]^{+}$calcd for $\mathrm{C}_{16} \mathrm{H}_{19} \mathrm{~N}_{3} \mathrm{O}_{2} \mathrm{~S}: 318.1276$; found: 318.1278 .

\section{4-(Dimethylamino)- $N$ - $[\{[4-($ dimethylamino)benzoyl $]$ amino $\}(4-$} methylphenyl)oxido- $\boldsymbol{\lambda}^{6}$-sulfanylidene]benzamide (10)

Byproduct $\mathbf{1 0}$ was isolated when $\mathbf{9}$ was prepared according to the general monoacylation procedure.

Yield: $6 \mathrm{mg}$ (1\%); brown solid; $\mathrm{mp} 125-127^{\circ} \mathrm{C}$.

${ }^{1} \mathrm{H}$ NMR (400 MHz, $\left.\mathrm{CD}_{3} \mathrm{OD}\right): \delta=8.02(\mathrm{~d}, J=8.3 \mathrm{~Hz}, 2 \mathrm{H}), 7.90(\mathrm{~d}, J=8.9$ $\mathrm{Hz}, 4 \mathrm{H}), 7.36$ (d, J = 8.2 Hz, $2 \mathrm{H}), 6.70$ (d, J = 8.9 Hz, $4 \mathrm{H}), 3.03(\mathrm{~s}, 12 \mathrm{H})$, $2.42(\mathrm{~s}, 3 \mathrm{H})$.

${ }^{13} \mathrm{C}$ NMR (101 MHz, $\left.\mathrm{CD}_{3} \mathrm{OD}\right): \delta=154.9,144.8,131.9,130.2,129.2$, 111.8, 40.2, 21.5.

HRMS (ESI): $m / z[\mathrm{M}+\mathrm{H}]^{+}$calcd for $\mathrm{C}_{25} \mathrm{H}_{28} \mathrm{~N}_{4} \mathrm{O}_{3} \mathrm{~S}$ : 465.1960; found: 465.1963.

\section{$N$-[Amino(4-methylphenyl)oxido- $\lambda^{6}$-sulfanylidene]-4-methoxy- benzamide (11)}

Yield: $107 \mathrm{mg}$ (35\%); white solid; $\mathrm{mp} 145-146{ }^{\circ} \mathrm{C}$.

${ }^{1} \mathrm{H}$ NMR $\left(400 \mathrm{MHz}\right.$, DMSO- $d_{6}$ ): $\delta=7.88-7.96$ (m, $2 \mathrm{H}$ ), 7.80 (d, $J=8.3$ $\mathrm{Hz}, 2 \mathrm{H}), 7.68$ (s, $2 \mathrm{H}), 7.38$ (d, J = 8.3 Hz, $2 \mathrm{H}$ ), 6.91-7.00 (m, $2 \mathrm{H}), 3.79$ (s, $3 \mathrm{H}), 2.37$ (s, $3 \mathrm{H})$.

${ }^{13} \mathrm{C}$ NMR $\left(101 \mathrm{MHz}\right.$, DMSO- $\left.d_{6}\right): \delta=170.8,162.1,142.6,139.9,130.6$, 129.2, 128.7, 126.8, 113.2, 55.3, 20.9.

HRMS (ESI): $m / z[\mathrm{M}+\mathrm{H}]^{+}$calcd for $\mathrm{C}_{15} \mathrm{H}_{16} \mathrm{~N}_{2} \mathrm{O}_{3} \mathrm{~S}: 305.0960$; found: 305.0936 .

\section{$\mathrm{N}$-[Amino(4-methylphenyl)oxido- $\lambda^{6}$-sulfanylidene]-3-chloro-4- methoxybenzamide (12)}

Yield: $121 \mathrm{mg}$ (36\%); white solid; $\mathrm{mp} 135-136{ }^{\circ} \mathrm{C}$.

${ }^{1} \mathrm{H}$ NMR (400 MHz, DMSO- $\left.d_{6}\right): \delta=8.08(\mathrm{~s}, 1 \mathrm{H}), 7.99(\mathrm{~d}, J=8.6 \mathrm{~Hz}, 1$ H), 7.82-7.97 (m, $4 \mathrm{H}), 7.51(\mathrm{~d}, J=7.8 \mathrm{~Hz}, 2 \mathrm{H}), 7.30(\mathrm{~d}, J=8.6 \mathrm{~Hz}, 1 \mathrm{H})$, $4.02(\mathrm{~s}, 3 \mathrm{H}), 2.50$ (s, $3 \mathrm{H})$.

${ }^{13} \mathrm{C}$ NMR $\left(101 \mathrm{MHz}\right.$, DMSO- $\left.d_{6}\right): \delta=169.5,157.1,142.7,139.5,130.2$, $129.5,129.3,129.1,126.9,120.4,112.0,56.4,20.9$.

HRMS (ESI): $m / z[\mathrm{M}+\mathrm{H}]^{+}$calcd for $\mathrm{C}_{15} \mathrm{H}_{15} \mathrm{ClN}_{2} \mathrm{O}_{3} \mathrm{~S}$ : 339.0570 ; found: 339.0587.
$N$-[Amino(4-methylphenyl)oxido- $\lambda^{6}$-sulfanylidene]pyridine-3carboxamide (13)

Yield: $125 \mathrm{mg}$ (45\%); white solid; $\mathrm{mp} 138-139{ }^{\circ} \mathrm{C}$.

${ }^{1} \mathrm{H}$ NMR (400 MHz, DMSO- $d_{6}$ ): $\delta=9.09(\mathrm{~d}, J=2.10 \mathrm{~Hz}, 1 \mathrm{H}), 8.69$ (dd, $J=1.8,4.8 \mathrm{~Hz}, 1 \mathrm{H}), 8.22(\mathrm{dt}, J=1.8,7.9 \mathrm{~Hz}, 1 \mathrm{H}), 7.87(\mathrm{~s}, 2 \mathrm{H}), 7.83(\mathrm{~d}$, $J=8.3 \mathrm{~Hz}, 2 \mathrm{H}), 7.46(\mathrm{dd}, J=4.8,7.9 \mathrm{~Hz}, 1 \mathrm{H}), 7.41(\mathrm{~d}, J=8.3 \mathrm{~Hz}, 2 \mathrm{H})$, $2.38(\mathrm{~s}, 3 \mathrm{H})$.

${ }^{13} \mathrm{C}$ NMR $\left(101 \mathrm{MHz}\right.$, DMSO- $\left.d_{6}\right): \delta=169.8,152.2,149.9,142.9,139.2$, 136.0, 131.4, 129.4, 126.9, 123.4, 21.0.

HRMS (ESI): $m / z[M+H]^{+}$calcd for $\mathrm{C}_{13} \mathrm{H}_{13} \mathrm{~N}_{3} \mathrm{O}_{2} \mathrm{~S}: 276.0807$; found: 276.0791.

\section{$N$-[Amino(4-methylphenyl)oxido- $\lambda^{6}$-sulfanylidene]pyridine-2- carboxamide (14)}

To a mixture of picolinic acid (123 mg, $1 \mathrm{mmol})$ and DMF (10 $\mu \mathrm{L})$ in MeCN (6 mL) was dropwise added a solution of oxalyl chloride (381 $\mathrm{mg}, 3 \mathrm{mmol})$ in $\mathrm{MeCN}(10 \mathrm{~mL})$ within $3 \mathrm{~min}$ at $0{ }^{\circ} \mathrm{C}$. The mixture was warmed from $0{ }^{\circ} \mathrm{C}$ to r.t. over $4 \mathrm{~h}$, and then was stirred at r.t. for $20 \mathrm{~h}$. The mixture was concentrated in vacuo to give a black solid. To the solid was added $\mathrm{MeCN}(3 \mathrm{~mL})$ and toluene $(3 \mathrm{~mL})$. The mixture was concentrated again in vacuo to give a black solid. The yield for the conversion was assumed to be $100 \%$. Without further purification, the fresh crude was used for the synthesis of compound $\mathbf{1 4}$ using the general monoacylation procedure, but with 2 equivalents of pyridazine. The final product was purified by preparative HPLC on a Kromasil c8 column ( $10 \mu \mathrm{m}, 250 \times 50 \mathrm{~mm}$ ID) using a gradient of $0-60 \%$ $\mathrm{MeCN}$ in $\mathrm{H}_{2} \mathrm{O} / \mathrm{MeCN} / \mathrm{AcOH}$ 95:5:0.2 buffer over 20 min with a flow rate of $100 \mathrm{~mL} / \mathrm{min}$ and $U V$ detection at $267 \mathrm{~nm}$.

Yield: $16 \mathrm{mg}$ (10\%); black oil.

${ }^{1} \mathrm{H}$ NMR (400 MHz, $\left.\mathrm{CD}_{3} \mathrm{OD}\right): \delta=8.60(\mathrm{~d}, J=4.5 \mathrm{~Hz}, 1 \mathrm{H}), 8.14(\mathrm{~d}, J=7.9$ $\mathrm{Hz}, 1 \mathrm{H}), 7.86-7.98$ (m, $3 \mathrm{H}), 7.48-7.56(\mathrm{~m}, 1 \mathrm{H}), 7.39$ (d, $J=8.2 \mathrm{~Hz}, 2$ $\mathrm{H}), 2.42(\mathrm{~s}, 3 \mathrm{H})$.

${ }^{13} \mathrm{C}$ NMR $\left(101 \mathrm{MHz}, \mathrm{CD}_{3} \mathrm{OD}\right): \delta=172.7,153.9,149.9,145.3,139.8$, 138.8, 130.6, 128.5, 127.6, 125.4, 21.5 .

HRMS (ESI): $m / z[M+H]^{+}$calcd for $\mathrm{C}_{13} \mathrm{H}_{13} \mathrm{~N}_{3} \mathrm{O}_{2} \mathrm{~S}: 276.0807$; found: 276.0803 .

\section{$N$-[Amino(4-methylphenyl)oxido- $\lambda^{6}$-sulfanylidene]pyridine-4- carboxamide (15)}

Yield: $154 \mathrm{mg}$ (56\%); off-white solid; $\mathrm{mp} 162-165^{\circ} \mathrm{C}$.

${ }^{1} \mathrm{H}$ NMR (400 MHz, DMSO- $d_{6}$ ): $\delta=8.64-8.73(\mathrm{~m}, 2 \mathrm{H}), 7.91(\mathrm{br} \mathrm{s}, 2 \mathrm{H})$, $7.83(\mathrm{~d}, J=8.3 \mathrm{~Hz}, 2 \mathrm{H}), 7.76-7.81(\mathrm{~m}, 2 \mathrm{H}), 7.41(\mathrm{~d}, J=8.3 \mathrm{~Hz}, 2 \mathrm{H})$, 2.39 (s, $3 \mathrm{H})$.

${ }^{13} \mathrm{C}$ NMR $\left(101 \mathrm{MHz}\right.$, DMSO- $\left.d_{6}\right): \delta=169.7,150.2,143.2,143.1,139.0$, 129.4, 127.0, 122.2, 21.0.

HRMS (ESI): $m / z[\mathrm{M}+\mathrm{H}]^{+}$calcd for $\mathrm{C}_{13} \mathrm{H}_{13} \mathrm{~N}_{3} \mathrm{O}_{2} \mathrm{~S}: 276.0807$; found: 276.0786 .

$N$-[Amino(4-methylphenyl)oxido- $\lambda^{6}$-sulfanylidene]-5-methyl-1,2oxazole-3-carboxamide (16)

Yield: $209 \mathrm{mg}$ (75\%); orange solid; $\mathrm{mp} 110-111^{\circ} \mathrm{C}$.

${ }^{1} \mathrm{H}$ NMR (400 MHz, DMSO- $d_{6}$ ): $\delta=7.97(\mathrm{~s}, 2 \mathrm{H}$ ), $7.82(\mathrm{~d}, J=8.3 \mathrm{~Hz}, 2$ H), $7.42(\mathrm{~d}, J=8.3 \mathrm{~Hz}, 2 \mathrm{H}), 6.36(\mathrm{~s}, 1 \mathrm{H}), 2.41(\mathrm{~s}, 3 \mathrm{H}), 2.39(\mathrm{~s}, 3 \mathrm{H})$.

${ }^{13} \mathrm{C}$ NMR $\left(101 \mathrm{MHz}\right.$, DMSO- $\left.d_{6}\right): \delta=170.5,164.7,161.2,143.2,138.8$, 129.4, 127.0, 102.0, 21.0, 11.8.

HRMS (ESI): $m / z[\mathrm{M}+\mathrm{H}]^{+}$calcd for $\mathrm{C}_{12} \mathrm{H}_{13} \mathrm{~N}_{3} \mathrm{O}_{3} \mathrm{~S}$ : 280.0756; found: 280.0764 . 
Ethyl 3-[2-(4-Methylphenyl)-2-oxido-2 $\lambda^{6}$-diazathi-1-en-1-yl]-3oxopropanoate (17)

Yield: $100 \mathrm{mg}$ (35\%); yellow oil.

${ }^{1} \mathrm{H}$ NMR (400 MHz, $\mathrm{CDCl}_{3}$ ): $\delta=7.89$ (d, $\left.J=8.3 \mathrm{~Hz}, 2 \mathrm{H}\right), 7.34$ (d, $J=8.3$ $\mathrm{Hz}, 2 \mathrm{H}), 6.04$ (br s, $2 \mathrm{H}), 4.17(\mathrm{q}, J=7.1 \mathrm{~Hz}, 2 \mathrm{H}), 3.41(\mathrm{~d}, J=3.8 \mathrm{~Hz}, 2$ H), $2.44(\mathrm{~s}, 3 \mathrm{H}), 1.25(\mathrm{t}, J=7.1 \mathrm{~Hz}, 3 \mathrm{H})$.

${ }^{13} \mathrm{C}$ NMR $\left(101 \mathrm{MHz}, \mathrm{CDCl}_{3}\right): \delta=174.5,168.1,145.0,137.5,130.0$, $126.9,61.3,46.7,21.8,14.2$.

HRMS (ESI): $m / z[M+H]^{+}$calcd for $\mathrm{C}_{12} \mathrm{H}_{16} \mathrm{~N}_{2} \mathrm{O}_{4} \mathrm{~S}: 285.0909$; found: 285.0896 .

\section{Ethyl 4-[2-(4-Methylphenyl)-2-oxido-2 ${ }^{6}$-diazathi-1-en-1-yl]-4- oxobutanoate (18)}

Yield: $211 \mathrm{mg}$ (71\%); white solid, which solidified from a colorless oil upon standing at r.t. over $2 \mathrm{~d}$; $\mathrm{mp} 92-93^{\circ} \mathrm{C}$.

${ }^{1} \mathrm{H} \mathrm{NMR}\left(400 \mathrm{MHz}, \mathrm{CDCl}_{3}\right): \delta=7.85(\mathrm{~d}, J=8.3 \mathrm{~Hz}, 2 \mathrm{H}), 7.32(\mathrm{~d}, J=8.3$ $\mathrm{Hz}, 2 \mathrm{H}), 6.09$ (br s, $2 \mathrm{H}), 4.10$ (q, J = 7.1 Hz, $2 \mathrm{H}), 2.66-2.76(\mathrm{~m}, 2 \mathrm{H})$, 2.56-2.63 (m, $2 \mathrm{H}), 2.43(\mathrm{~s}, 3 \mathrm{H}), 1.22(\mathrm{t}, J=7.1 \mathrm{~Hz}, 3 \mathrm{H})$.

${ }^{13} \mathrm{C}$ NMR $\left(101 \mathrm{MHz}, \mathrm{CDCl}_{3}\right): \delta=180.4,173.0,144.7,138.1,129.9$, $126.8,60.6,34.6,29.9,21.7,14.3$.

HRMS (ESI): $m / z[\mathrm{M}+\mathrm{H}]^{+}$calcd for $\mathrm{C}_{13} \mathrm{H}_{18} \mathrm{~N}_{2} \mathrm{O}_{4} \mathrm{~S}: 299.1065$; found: 299.1062 .

\section{$N$-[Amino(4-methylphenyl)oxido- $\lambda^{6}$-sulfanylidene]butanamide}

(19)

Yield: $190 \mathrm{mg}$ (79\%); white solid; $\mathrm{mp} 89-90{ }^{\circ} \mathrm{C}$.

${ }^{1} \mathrm{H}$ NMR (400 MHz, $\mathrm{CDCl}_{3}$ ): $\delta=7.85(\mathrm{~d}, J=8.3 \mathrm{~Hz}, 2 \mathrm{H}), 7.32(\mathrm{~d}, J=8.3$ Hz, 2 H), 6.16 (br s, 2 H), 2.43 (s, 3 H), 2.35 (t, J = 7.4 Hz, 2 H), 1.66 (dt, $J=7.4,14.8 \mathrm{~Hz}, 2 \mathrm{H}), 0.92(\mathrm{t}, J=7.4 \mathrm{~Hz}, 3 \mathrm{H})$.

${ }^{13} \mathrm{C}$ NMR $\left(101 \mathrm{MHz}, \mathrm{CDCl}_{3}\right): \delta=182.5,144.6,138.5,129.9,126.7,42.1$, 21.7, 19.1, 13.9.

HRMS (ESI): $m / z[M+\mathrm{H}]^{+}$calcd for $\mathrm{C}_{11} \mathrm{H}_{16} \mathrm{~N}_{2} \mathrm{O}_{2} \mathrm{~S}: 241.1010$; found: 241.1009.

$N$-[Amino(4-methylphenyl)oxido- $\lambda^{6}$-sulfanylidene]-2,2-dimethylpropanamide (20) ${ }^{24}$

Yield: $235 \mathrm{mg}$ (92\%); white solid; $\mathrm{mp} 109-110{ }^{\circ} \mathrm{C}$ (Lit. ${ }^{24} 110{ }^{\circ} \mathrm{C}$ ).

${ }^{1} \mathrm{H} \mathrm{NMR}\left(400 \mathrm{MHz}, \mathrm{CDCl}_{3}\right): \delta=7.83(\mathrm{~d}, J=8.3 \mathrm{~Hz}, 2 \mathrm{H}), 7.31$ (d, $J=8.3$ $\mathrm{Hz}, 2 \mathrm{H}), 6.10$ (s, $2 \mathrm{H}), 2.43$ (s, $3 \mathrm{H}), 1.19$ (s, $9 \mathrm{H})$.

${ }^{13} \mathrm{C}$ NMR $\left(101 \mathrm{MHz}, \mathrm{CDCl}_{3}\right): \delta=188.1,144.4,138.7,129.9,126.5,41.7$, 27.7, 21.7.

HRMS (ESI): $m / z[\mathrm{M}+\mathrm{H}]^{+}$calcd for $\mathrm{C}_{12} \mathrm{H}_{18} \mathrm{~N}_{2} \mathrm{O}_{2} \mathrm{~S}$ : 255.1167; found: 255.1159 .

$N$-[Amino(4-methylphenyl)oxido- $\lambda^{6}$-sulfanylidene]-2-(benzyloxy)acetamide (21)

Yield: $248 \mathrm{mg}$ (78\%); colorless oil.

${ }^{1} \mathrm{H} \mathrm{NMR}\left(400 \mathrm{MHz}, \mathrm{CDCl}_{3}\right): \delta=7.86(\mathrm{~d}, J=8.3 \mathrm{~Hz}, 2 \mathrm{H}), 7.27-7.4(\mathrm{~m}, 7$ H), 6.17 (br s, $2 \mathrm{H}), 4.62(\mathrm{~s}, 2 \mathrm{H}), 4.11(\mathrm{~d}, J=3.6 \mathrm{~Hz}, 2 \mathrm{H}), 2.43(\mathrm{~s}, 3 \mathrm{H})$.

${ }^{13} \mathrm{C}$ NMR $\left(101 \mathrm{MHz}, \mathrm{CDCl}_{3}\right): \delta=178.1,178.1,144.9,138.0,138.0$, 137.6, 130.0, 128.5, 128.2, 128.0, 126.8, 73.4, 71.3, 21.7.

HRMS (ESI): $m / z$ [M $+\mathrm{H}]^{+}$calcd for $\mathrm{C}_{16} \mathrm{H}_{18} \mathrm{~N}_{2} \mathrm{O}_{3} \mathrm{~S}$ : 319.1116; found: 319.1119.
Ethyl [Amino(4-methylphenyl)oxido- $\lambda^{6}$-sulfanylidene]carbamate (22)

Yield: $225 \mathrm{mg}$ (93\%); yellow solid; $\mathrm{mp} 132-133{ }^{\circ} \mathrm{C}$.

${ }^{1} \mathrm{H}$ NMR (400 MHz, DMSO- $d_{6}$ ): $\delta=7.74(\mathrm{~d}, J=8.3 \mathrm{~Hz}, 2 \mathrm{H}$ ), $7.63(\mathrm{~s}, 2$ $\mathrm{H}), 7.39(\mathrm{~d}, J=8.3 \mathrm{~Hz}, 2 \mathrm{H}), 3.73-3.91(\mathrm{~m}, 2 \mathrm{H}), 2.38(\mathrm{~s}, 3 \mathrm{H}), 1.04(\mathrm{t}, J=$ $7.1 \mathrm{~Hz}, 3 \mathrm{H})$.

${ }^{13} \mathrm{C}$ NMR $\left(101 \mathrm{MHz}\right.$, DMSO- $\left.d_{6}\right): \delta=157.3,142.6,139.7,129.3,126.8$, $60.2,20.9,14.3$.

HRMS (ESI): $m / z[M+\mathrm{H}]^{+}$calcd for $\mathrm{C}_{10} \mathrm{H}_{14} \mathrm{~N}_{2} \mathrm{O}_{3} \mathrm{~S}$ : 243.0803; found: 243.0797.

$N$-[(Butanoylamino)(4-methylphenyl)oxido- $\lambda^{6}$-sulfanylidene]benzamide (23)

3 (102 mg, $0.37 \mathrm{mmol}$ ) and $\mathrm{Et}_{3} \mathrm{~N}$ stock solution in $\mathrm{MeCN}(0.57 \mathrm{M}$; $1.076 \mathrm{~mL}, 0.61 \mathrm{mmol})$ were mixed in $\mathrm{MeCN}(2 \mathrm{~mL})$ at r.t. To the mixture was added butyryl chloride stock solution in $\mathrm{MeCN}(0.38 \mathrm{M}$; $1.076 \mathrm{~mL}, 0.41 \mathrm{mmol}$ ) in one portion. The mixture was stirred at r.t. for $40 \mathrm{~min}$. LCMS showed full conversion. To the mixture was added $26 \%$ aq $\mathrm{NH}_{4} \mathrm{OH}(0.1 \mathrm{~mL})$ to consume the excess acyl chloride. The mixture was concentrated, and the resulting residue was dissolved in a mixture of DMSO $(10 \mathrm{~mL})$ and formic acid $(0.2 \mathrm{~mL})$. The compound was purified by preparative HPLC on a Kromasil C8 column $(10 \mu \mathrm{m}$, $250 \times 50 \mathrm{~mm}$ ID) using a gradient of $20-95 \% \mathrm{MeCN}$ in $\mathrm{H}_{2} \mathrm{O} / \mathrm{MeCN} /$ formic acid 95:5:0.2 buffer over 20 min with a flow rate of $100 \mathrm{~mL} / \mathrm{min}$ and UV detection at $250 \mathrm{~nm}$.

Yield: $119 \mathrm{mg}$ (93\%); white solid; $\mathrm{mp} 60-62{ }^{\circ} \mathrm{C}$.

${ }^{1} \mathrm{H}$ NMR (400 MHz, DMSO- $d_{6}$ ): $\delta=8.01-8.06$ (m, $2 \mathrm{H}$ ), 7.91 (d, $J=8.4$ $\mathrm{Hz}, 2 \mathrm{H}), 7.54-7.61(\mathrm{~m}, 1 \mathrm{H}), 7.42-7.51(\mathrm{~m}, 4 \mathrm{H}), 2.40(\mathrm{~s}, 3 \mathrm{H}), 2.25(\mathrm{t}$, $J=7.2 \mathrm{~Hz}, 2 \mathrm{H}$ ), 1.43 (sextet, $J=7.3 \mathrm{~Hz}, 2 \mathrm{H}$ ), 0.77 (t, $J=7.3 \mathrm{~Hz}, 3 \mathrm{H}$ ).

${ }^{13} \mathrm{C}$ NMR $\left(101 \mathrm{MHz}\right.$, DMSO- $\left.d_{6}\right): \delta=172.0,171.3,144.4,135.7,135.5$, 132.4, 129.7, 129.0, 128.3, 127.8, 37.4, 21.1, 17.6, 13.2.

HRMS (ESI): $m / z[M+H]^{+}$calcd for $\mathrm{C}_{18} \mathrm{H}_{20} \mathrm{~N}_{2} \mathrm{O}_{3} \mathrm{~S}$ : 345.1273; found: 345.1264 .

\section{Acknowledgment}

The author thanks Anders M. Johansson for useful comments on the manuscript. The author also thanks the Structure Analysis, Separation, and Compound Management teams, AstraZeneca R\&D Mölndal for assistance.

\section{Supporting Information}

Supporting information for this article is available online at http://dx.doi.org/10.1055/s-0035-1561339.

\section{References}

(1) Bach, P.; Antonsson, T.; Bylund, R.; Björkman, J.; Österlund, K.; Giordanetto, F.; van Giezen, J. J. J.; Andersen, S.; Zachrisson, H.; Zetterberg, F. J. Med. Chem. 2013, 56, 7015.

(2) Rosenquist, Å.; Samuelsson, B.; Johansson, P.-O.; Cummings, M. D.; Lenz, O.; Raboisson, P.; Simmen, K.; Vendeville, S.; de Kock, H.; Nilsson, M.; Horvath, A.; Kalmeijer, R.; de la Rosa, G.; Beumont-Mauviel, M. J. Med. Chem. 2014, 57, 1673. 
Synthesis

(3) Souza, D. G.; Bertini, R.; Vieira, A. T.; Cunha, F. Q.; Poole, S.; Allegretti, M.; Colotta, F.; Teixeira, M. M. Br. J. Pharmacol. 2004, 143, 132.

(4) Asaki, T.; Hamamoto, T.; Sugiyama, Y.; Kuwano, K.; Kuwabara, K. Bioorg. Med. Chem. 2007, 15, 6692.

(5) Leca, D.; Toussaint, A.; Mareau, C.; Fensterbank, L.; Lacôte, E.; Malacria, M. Org. Lett. 2004, 6, 3573.

(6) Sehgelmeble, F.; Janson, J.; Ray, C.; Rosqvist, S.; Gustavsson, S.; Nilsson, L. I.; Minidis, A.; Holenz, J.; Rotticci, D.; Lundkvist, J.; Arvidsson, P. I. ChemMedChem 2012, 7, 396.

(7) Pemberton, N.; Graden, H.; Evertsson, E.; Bratt, E.; Lepistoe, M.; Johannesson, P.; Svensson, P. H. ACS Med. Chem. Lett. 2012, 3, 574.

(8) Levchenko, E. S.; Berzina, I. Probl. Proiskhozhdeniya Nefti 1967, 177; Chem. Abstr. 1968, 69, 2652.

(9) Worch, C.; Atodiresei, I.; Raabe, G.; Bolm, C. Chem. Eur. J. 2010, $16,677$.

(10) Steurer, M.; Bolm, C. J. Org. Chem. 2010, 75, 3301.

(11) Borhade, S. R.; Sandstroem, A.; Arvidsson, P. I. Org. Lett. 2013, 15, 1056.

(12) Chen, Y.; Gibson, J. RSC Adv. 2015, 5, 4171.
(13) Borhade, S. R.; Svensson, R.; Brandt, P.; Artursson, P.; Arvidsson, P. I.; Sandstroem, A. ChemMedChem 2015, 10, 455.

(14) Adibi, H.; Massah, A. R.; Majnooni, M. B.; Shahidi, S.; Afshar, M.; Abiri, R.; Naghash, H. J. Synth. Commun. 2010, 40, 2753.

(15) Martin, M. T.; Roschangar, F.; Eaddy, J. F. Tetrahedron Lett. 2003, $44,5461$.

(16) Fu, S.; Lian, X.; Ma, T.; Chen, W.; Zheng, M.; Zeng, W. Tetrahedron Lett. 2010, 51, 5834.

(17) Xie, W.; Yang, J.; Wang, B.; Li, B. J. Org. Chem. 2014, 79, 8278.

(18) Dalisay, D. S.; Tsukamoto, S.; Molinski, T. F.J. Nat. Prod. 2009, 72, 353.

(19) Akhlaghinia, B.; Rouhi-Saadabad, H. Can. J. Chem. 2013, 91, 181.

(20) Nakonieczna, L.; Milewska, M.; Kolasa, T.; Chimiak, A. Synthesis 1985, 929.

(21) Katritzky, A. R.; He, H.; Suzuki, K. J. Org. Chem. 2000, 65, 8210.

(22) Kirij, N. V.; Pasenok, S. V.; Yagupolskii, Y. L.; Naumann, D.; Tyrra, W. J. Fluorine Chem. 1994, 69, 219.

(23) Osajda, M.; Mlochowski, J. Pol. J. Chem. 2002, 76, 953.

(24) Azzaro, S.; Desage-El Murr, M.; Fensterbank, L.; Lacôte, E.; Malacria, M. Synlett 2011, 849. 